\title{
EFFECT OF FEEDING DIETS CONTAINING DRIED GREEN BEAN (PHASEOLUS VULGARIS L.) VINES ON PERFORMANCE OF GROWING APRI RABBITS
}

\author{
Amany A. Khayyal, W. A. Morsy and Amira S. El-Deghadi \\ Animal Production Research Institute, Agricultural Research Center, Ministry of Agriculture, \\ Dokki, Giza, Egypt.
}

(Received 29/10/2017, accepted 30/11/2017)

\section{SUMMARY}

A total of seventy APRI rabbits were chosen after weaned at 5 weeks of age and randomly divided into 5 similar groups (14 rabbits/group) according to their initial live body weight $(656.96 \pm 2.67 \mathrm{~g})$, to evaluate the utilization of dried green bean vines $(\mathrm{GBV})$ in feeding growing rabbits and its effect on growth performance, nutrients digestibilities, carcass traits, some blood parameters, cecum activity as well as economic efficiency. Rabbits were fed ad-libitum on diets containing 0, 10, 20, 30 and 40\% dried GBV for groups D1, D2, D3, D4 and D5, respectively. The five diets were formulated according to the Agriculture Ministry Decree Recommendation (1996). At the end of the experimental period ( 15 weeks of age), digestibility trials were carried out to determine the digestibility and the feeding values of the experimental diets. In addition, four rabbits were slaughtered from each group to test the carcass traits, some blood parameters and cecum activity. The experimental diets were fed to growing rabbits for 10 weeks post-weaning period. Results revealed that the dried GBV contained $2243 \mathrm{kcal}$ digestible energy $/ \mathrm{kg}, 12.70 \%$ crude protein, $21.59 \%$ crude fiber, $1.60 \%$ ether extract, $15.77 \%$ ash, $2.05 \%$ calcium $0.18 \%$ phosphorus and amino acids such as $1.02 \%$ aspartic acid, $0.90 \%$ glutamic acid, $0.12 \%$ methionine and $0.40 \%$ lysine (as fed). Final body weights (at 15 weeks of age) were insignificant higher with tested diets (D2, D3 and D4) and significant lower with tested diets (D5), compared with control one (D1). The same trend among the experimental diets was observed with the total weight gain over 5-15 weeks. Total feed intake during the whole experimental period was significant lower with D5, compared to that of D2, D3, D4 and control diet (D1). Feed conversion was insignificant better with diets contained 10 up to $30 \%$ dried GBV than that of control one, while the diet contained the highest level of dried GBV (D5) was achieved significantly the worst one in comparison of control diet, over the whole experimental period. In comparison with control diet, most nutrients digestibilities of most tested diets did not affected significantly. Diets involved up to $30 \%$ dried GBV had achieved the best results in respect of pre-slaughter weight and empty carcass weight as well as dressing percentage in comparison with control and the other tested diets (D4 and D5). Level of 10, 20 and 30\% dried GBV recorded insignificantly higher values of CP and ash contents and the lowest content of EE of rabbit meat compared to the control and D5 groups. Dried GBV had slightly changes on blood constituents of experimental rabbits. Insignificantly higher concentrations of TVFA's were observed in the cecum contents of rabbits fed on the different levels of dried GBV compared to the control group. Inversely $\mathrm{pH}$ of cecum content and ammonia- $\mathrm{N}$ concentrations were insignificantly decreased compared with control diet. While cecum weight had significantly the highest value in D5 diet. Profitability and economic efficiency were markedly improved with dried GBV up to $30 \%$ compared to control diet. In conclusion dried GBV could be used in feeding of growing rabbits up to $30 \%$ with no adverse effect on productive performance, carcass traits, physiological functions and economic efficiency.

Keywords: Rabbits, green bean vines, productive performance, digestibility, carcass traits, blood parameters, cecum activity, and economic efficiency.

\section{INTRODUCTION}

Egypt faces an acute problem of inadequate quality and quantity of animal feeds, especially during the summer. Excessively such problem is due to limited land resources and the high competition between human and livestock for high quality grains and protein supplements. It is well known that the feeding cost represents about $60-70 \%$ of the total production cost. The challenge for the feed 
formulation is to obtain the least cost diets that fully match with animal requirements (Maertens et al., 2002). Therefore, efforts have been made towards the solution of feed shortage by improving the conventional sources and investigating for more unconventional feeds. Minimizing the feed cost could be achieved through the use of untraditional cheaper feed ingredients or improving utilization of common feeds by using some feed additives. Vegetable residues are the plant materials that remained after harvesting of vegetable crops. Most of them are beneficially used as organic fertilizers or burned causing an environmental pollution, but some are dried and stored as forage sources for ruminants or other may be left in the field as grazing for livestock (Renard, 2001). Some studies designed to utilize from some agricultural and agro-industrial by products in rabbit feeding. Mutetikka et al. (1990) found that the use of untraditional feedstuffs such as the agricultural by-products in the diets may helps in solving the problem of feed shortage and decrease the cost of feeding. Crop residues, such as dried pods and stems (straw) and processing by-products (discarded pods) can be used as animal feed (Wortmann, 2006). Bean crop residues (straw) can be fed to livestock as fresh, or after ensiling. It can be mixed with grains in order to increase the protein content of the silage (Linn et al., 2002). Green bean (Phaseolus vulgaris L.) is considered one of the most important vegetable crops grown in Egypt, and occupies a great part of local consumption and export (El-Noemani et al., 2010). Green bean crop cultivation has been increased in Egypt during the last three decades to be 257.5 tones yearly (Agriculture Economics and Statistics, 2014). The vines of green bean are estimated to represent approximately $50 \%$ of the whole harvest crop while the proposed rate of exploitation of vegetative growth 25\% from this waste (Desuki and El-Noubi, 1990), so, there are many tones of green bean wastes that could be participate in solving the feedstuffs shortage problem and reduce the environmental pollution. Post-harvest by-products of Phaseolus vulgaris were manually separated into stems, leaves and empty pods. The green beans are considered one of the most important vegetable crops grown in Egypt, and represent a great part of local consumption and export. The cultivated area of green bean in Egypt is $2.4 \%$ of the total world cultivated area, producing about $3.5 \%$ of the total world production of bean (El-Noemani et al., 2010). Green beans and other beans, such as kidney beans, navy beans and black beans are all known scientifically as Phaseolus vulgaris -the common bean- which has been used throughout history for feeding both humans and animals. They are an important crop in areas with limited access to animal proteins or technological advances for further food processing. The seeds of several species of bean and particularly those from the genus Phaseolus have long been known to be a rich source of proteins, minerals, vitamins, and energy in diets for human and monogastric animals (Arija et al., 2006).

The objective of this study was to investigate the effect inclusion of dried green bean vines as nonconventional feed ingredient in rabbit diets on productive performance, digestibility of nutrients, carcass traits, some blood parameters, cecum activity and economic efficiency.

\section{MATERIALS AND METHODS}

This study was carried out during the period from April to June 2017 (for 10 weeks) at Sakha Research Station, Kafer El-Sheikh Governorate, Animal Production Research Institute (APRI), Agriculture Research Center (ARC), Ministry of Agriculture, Dokki, Giza, Egypt and the chemical analysis was carried out at laboratories of APRI, ARC. An ample amount of dried green bean vines (GBV) which included leaves, stem and empty pods was provided by Kalubaia Governorate, Egypt. The estimated amount of GBV was collected directly after harvest their grains and chopped to 2-3 cm pieces with moisture content of $77 \%$ approximately, then sun-air dried for 14 days, then completely ground before mixing with the other ingredients and stored in bags until use. Samples of the feed ingredients were analyzed for crude protein $(\mathrm{CP})$, crude fiber $(\mathrm{CF})$, ether extract (EE) and ash. Dried GBV were analyzed for acid detergent lignin (ADL) using Tecator Fibretic System according to Goering and Van Soest (1970) procedures. Minerals (calcium and total phosphorus) were determined in other samples which ashed in an oven at $600^{\circ} \mathrm{C}$ for 2 hours; digested with $\mathrm{HCl} 50 \%$ concentration in boiling water bath and then diluted with water to $100 \mathrm{ml}$. Minerals were determined using atomic absorption. Amino acids concentrations were measured using a Bekman 7300 high performance amino acids analyzer according to the methods of AOAC (1996) at the Central Laboratory for Foods and Feeding (CLFF), Agriculture Research Center, Giza, Egypt. The experimental diets were manufactured at El-Salam factory, El-Marg, Cairo Governorate. Proximate analysis was performed according to the 
methods of AOAC (1996). Ingredients and calculated chemical composition of the experimental diets are presented in Table (1). Also, chemical analysis and amino acid contents of dried green bean vines (GBV) are presented in Table 2.

\section{Housing and feeding system:}

Seventy APRI rabbits were chosen after weaned at 5 weeks of age and divided into 5 similar groups (14 rabbits/group) according to their initial live body weight $(656.96 \pm 2.67 \mathrm{~g})$. The experimental period extended from 5 to 15 weeks of age. Group D1 was fed the basal diet (control), while groups D2, D3, D4 and D5 were fed their diets which included dried GBV at rate of 10, 20, 30 and 40\%,

Table (1): Ingredients and calculated composition of the experimental diets (as fed).

\begin{tabular}{|c|c|c|c|c|c|}
\hline \multirow{2}{*}{ Item } & \multicolumn{5}{|c|}{ Experimental diets $\%$} \\
\hline & D1 & D2 & D3 & D4 & D5 \\
\hline \multicolumn{6}{|l|}{ Ingredients (\%): } \\
\hline Dried green bean vines & - & 10 & 20 & 30 & 40 \\
\hline Clover hay & 30.00 & 21.00 & 14.00 & 7.00 & - \\
\hline Yellow corn & 7.00 & 5.00 & 4.00 & 2.00 & - \\
\hline Barley & 20.00 & 18.60 & 17.00 & 16.00 & 15.00 \\
\hline Soybean meal & 16.50 & 15.90 & 15.50 & 15.00 & 14.50 \\
\hline Wheat bran & 20.00 & 23.00 & 23.00 & 23.50 & 24.00 \\
\hline Molasses & 4.00 & 4.00 & 4.00 & 4.00 & 4.00 \\
\hline DL-Methionine & 0.10 & 0.10 & 0.10 & 0.10 & 0.10 \\
\hline Vitamins \& minerals mixture $^{1}$ & 0.30 & 0.30 & 0.30 & 0.30 & 0.30 \\
\hline Salt & 0.50 & 0.50 & 0.50 & 0.50 & 0.50 \\
\hline Limestone & 1.05 & 1.05 & 1.05 & 1.05 & 1.05 \\
\hline Di-Calcium phosphate & 0.35 & 0.35 & 0.35 & 0.35 & 0.35 \\
\hline Anti-Fungi & 0.10 & 0.10 & 0.10 & 0.10 & 0.10 \\
\hline Anti- Coccidia & 0.10 & 0.10 & 0.10 & 0.10 & 0.10 \\
\hline Total & 100 & 100 & 100 & 100 & 100 \\
\hline \multicolumn{6}{|l|}{ Calculated composition $^{2}$ : } \\
\hline Dry matter (DM), \% & 87.04 & 87.24 & 87.48 & 87.72 & 87.96 \\
\hline Organic matter $(\mathrm{OM}), \%$ & 81.18 & 80.51 & 79.87 & 79.20 & 78.53 \\
\hline Crude protein $(\mathrm{CP}), \%$ & 17.01 & 17.07 & 17.05 & 17.07 & 17.08 \\
\hline Ether extract (EE), \% & 2.35 & 2.33 & 2.26 & 2.19 & 2.12 \\
\hline Nitrogen free extract (NFE), \% & 48.25 & 47.93 & 47.43 & 46.84 & 46.25 \\
\hline Ash, \% & 5.86 & 6.73 & 7.61 & 8.52 & 9.43 \\
\hline Digestible energy $(\mathrm{DE})^{3}, \mathrm{kcal} / \mathrm{kg}$ & 2502 & 2516 & 2523 & 2524 & 2525 \\
\hline Crude fiber $(\mathrm{CF}), \%$ & 13.57 & 13.19 & 13.12 & 13.10 & 13.08 \\
\hline NDF, $\%$ & 37.84 & 37.59 & 37.54 & 37.53 & 37.52 \\
\hline $\mathrm{ADF}, \%$ & 21.80 & 21.47 & 21.40 & 21.38 & 21.37 \\
\hline ADL, \% & 13.87 & 13.53 & 13.46 & 13.40 & 13.38 \\
\hline Hemicellulose, $\%$ & 16.04 & 16.12 & 16.14 & 16.15 & 16.15 \\
\hline Cellulose, $\%$ & 7.93 & 7.94 & 7.95 & 7.96 & 7.97 \\
\hline Calcium, \% & 1.02 & 1.10 & 1.20 & 1.31 & 1.41 \\
\hline Total phosphorus, $\%$ & 0.519 & 0.528 & 0.518 & 0.511 & 0.504 \\
\hline Methionine, \% & 0.36 & 0.35 & 0.35 & 0.34 & 0.34 \\
\hline Lysine, \% & 0.81 & 0.78 & 0.77 & 0.75 & 0.73 \\
\hline $\mathrm{DE}: \mathrm{CP}$ & 147.08 & 147.44 & 147.92 & 147.89 & 147.86 \\
\hline \multicolumn{6}{|c|}{$\begin{array}{l}\text { 1: Supplied per Kg of diet: } 12000 \mathrm{IU} \text { Vit. A; } 2200 \mathrm{IU} \text { Vit. D3; } 10 \mathrm{mg} \text { Vit. E; } 2.0 \mathrm{mg} \text { Vit. K3; } 1.0 \mathrm{mg} \text { Vit. B1; } 4.0 \mathrm{mg} \\
\text { Vit. B2; } 1.5 \mathrm{mg} \text { Vit. B6; 0.0010 mg Vit. B12; } 6.7 \mathrm{mg} \text { Vit. Pantothenic acid;6.67 mg Vit. B5; } 1.07 \mathrm{mg} \text { Biotin; 1.6) } \\
\text { mg Folic acid; } 400 \mathrm{mg} \text { Choline chloride; } 22.3 \mathrm{mg} \text { Zn;10 mg Mn; } 25 \mathrm{mg} \mathrm{Fe;1.67} \mathrm{mg} \mathrm{Cu;0.25mg} \mathrm{I;} \mathrm{0.033} \mathrm{mg} \mathrm{Se} \\
\text { and } 133.4 \mathrm{mg} \text { Mg.l. }\end{array}$} \\
\hline \multicolumn{6}{|l|}{ 2: According to MOA (2001). } \\
\hline \multicolumn{6}{|c|}{$\begin{array}{l}\text { 3: Calculated according to Cheeke }(1987): D E(\text { Kcal } / g)=4.36-0.0491(\% N D F) ; \% N D F=28.924+0.657 \\
(\% C F) ; \% A D F=9.432+0.912(\% C F) ; A D F=\text { cellulose+lignin; Hemicellulose }=\% N D F-\% A D F .\end{array}$} \\
\hline
\end{tabular}


respectively to evaluate the utilization of dried green bean (GBV) in feeding growing rabbits. The experimental diets were formulated to be iso-nitrogenous $(\sim 17 \% \mathrm{CP})$ and iso-caloric $(\sim 2500 \mathrm{Kcal}$ $\mathrm{DE} / \mathrm{Kg}$ diet). All diets were pelleted and contained adequate levels of nutrients to satisfy the nutrients requirements of growing rabbits according to Agriculture Ministry Decree (1996). Rabbits of each group were housed in galvanized wire batteries in a well-ventilated building (natural through the window) and offered the experimental pelleted diets at ad libitum. Fresh water was available at all times from automatic drinkers with nipples for each cage. Urine and feces dropped from cages on the floor were cleaned every day in the morning. All rabbits were observed daily, kept under the same managerial, hygienic and environmental conditions, and vaccinated against common diseases. All rabbits were individually weighed at the beginning of the experiment, then weekly before offering the morning meal until marketing age (15 weeks). Feed intake was weekly recorded during the experimental period. Live body weight, weight gain, feed intake, feed conversion (g feed/g gain), performance index \% (final live body weight (Kg)/ feed conversion x100) according to North (1981) and economic efficiency were estimated.

\section{Digestibility trials:}

At the end of the feeding trial (15 weeks of age), digestibility trials were carried out to determine the nutrients digestibilities and feeding values of the experimental diets. A total number of 15 male rabbits were taken randomly ( 3 within each treatment) and allotted in different treatments. Rabbits were housed individually in metabolic cage to facilitate the collection of all droppings throughout the digestibility trials. The same feeding regime used during the feeding trial was also followed during the digestibility trials. Feed intake was daily recorded and quantitative collection of feces was started 24 hours after offering the daily feed. Feces of each rabbit were collected every day in the morning for a collection period of 5 days, sprayed with $2 \%$ boric acid for trapping any ammonia released, then oven dried at $60^{\circ} \mathrm{C}$ till constant weight, finely ground and stored for chemical analysis. Digestion coefficients of nutrients and feeding values were calculated according to Abou-Raya (1967).

\section{Carcass traits:}

Four rabbits representing each dietary treatment were randomly chosen at the end of feeding trial, to study the different carcass traits. Rabbits were fasted for 12 hours and individually weighed to record the pre-slaughter weight. After complete bleeding and skinning, the empty carcass with head, liver, kidneys, heart, coat, intestine and cecum were weighed separately to the nearest gram. Percentages were estimated on relative to pre-slaughter weight. Edible giblets wt. $=$ liver wt. + kidneys wt. + heart wt., total edible parts wt.= empty carcass wt. (with head)+ edible giblets wt., dressing $\%=$ total edible parts wt / fasted wt. x100 according to Cheeke (1987). Meat of each carcass was separated and weighted. Then minced, dried, reweighed, ground and stored at $10^{\circ} \mathrm{C}$ for chemical analysis. Individual blood samples (from the same slaughtered rabbits) were collected in dry clean centrifuge tubes containing few drops of heparin solution and centrifuged at 4000 r.p.m for $15 \mathrm{~min}$. to separate blood plasma, and then stored at $-20^{\circ} \mathrm{C} \pm 1$ until the time of analysis to estimate some blood parameters. Various chemical parameters were calorimetrically determined using commercial kits; following the same steps as described by manufactures. Glucose concentration was determined according to Trinder (1969); cholesterol was estimated according to Stein (1986); total proteins (TP) was measured as described by the Biuret method according to Armstrong and Carr (1964); albumin (A) was assayed according to Doumas et al. (1971); globulin was calculated by subtracting the albumin value from total protein value; urea was detected according to Berthelot (1959); creatinine was measured according to Faulkner and King (1976), while liver functions were assessed by measuring the activities of aspartate aminotransferase (AST) and alanine aminotransferase (ALT) according to Reitman and Frankel (1957) Diets, feces and meat were analyzed according to AOAC (1996).

\section{Cecum activity:}

Samples of cecum contents were taken individually from the four animals of each treatment at the end of the experimental period after being fasted for $12 \mathrm{hrs}$. Cecum fluid samples were obtained after rabbits slaughtered and then strained through four folds of gauze and divided into three portions. The first portion was used immediately for the estimation $\mathrm{pH}$ of cecum contents by using $\mathrm{pH}$ meter and the second portion was used immediately for estimation of ammonia nitrogen concentration by applying Conway (1958), while the third portion was preserved by addition of $1 \mathrm{ml} \mathrm{N} / 10 \mathrm{HCL}$ and $2 \mathrm{ml}$ orthophosphoric acid to each $2 \mathrm{ml}$ of cecum contents juice for determination of total volatile fatty acids (TVFA's) according to Eadie et al. (1967). 


\section{Economic efficiency:}

Economic efficiency was calculated as the ratio between incomes price of weight gain and the cost of feed consumed over 5-15 weeks of age.

\section{Statistical analysis:}

Data were analyzed for all variables using the general linear models procedure to establish the differences between means using SAS software version 9.1 (SAS, 2004). Data of percentages were subjected to arc-sin transformation to approximate normal distribution before being analyzed. Variables having a significant F- test were compared using Duncan's multiple rang test (Duncan, 1955). All statements of statistical significance were based on probability $(\mathrm{P}<0.05)$. The model used was: $\mathrm{Y}_{\mathrm{ij}}=\mu$ $+T_{i}+e_{i j}$. Where: $Y_{i j}=$ the observation of $i j . \mu=$ the overall mean. $T_{i}=$ the effect of $i$ (treatments). $e_{i j}=$ the experimental random error.

\section{RESULTS AND DISCUSSION}

\section{Chemical analysis of dried green bean vines $(G B V)$ :}

The proximate chemical analysis and amino acid contents of dried GBV are presented in Table (2). Results showed that, dried GBV had reasonable values of protein and nitrogen free extract and high contents of ash and crude fiber particularly cellulose as well as in calcium. Moderate amount of ADL and low amounts of phosphorous and methionine were found. The present values are comparable to those reported by Gupta et al. (1993) who concluded that cull beans waste had potentiality used as livestock feed if processed suitably. Also findings here are similar to those obtained by Tag El-Din et al. (2002), Hussien (2009), Kathy and Robert (2009) and Elgohary and Abo EL-Maaty (2014). The dried GBV were rich in most essential amino acids particularly, aspartic acid and glutamic acid which is converted into glucose and helps to maintain the acid/alkaline balance (Christy, 2010) and were within the published range by Hussien et al. (1999) and Zaza et al. (2009). Tandon et al. (1957) reported that different Phaseolus beans contained tryptophan from 0.14 to $0.22 \%$, lysine from 1.69 to $2.42 \%$ and thiamin from 0.77 to 1.34 $\mathrm{mg} / 100 \mathrm{~g}$. Chemical composition of bean crop residues depends on the proportions of stems, pod husks and leaves (Sharasia et al., 2017). From the chemical analysis results, it is obviously concluded that dried green bean vines are rich in most nutrients and could be considering as a good feedstuff with high nutritive value in terms of DE.

Table (2): Chemical analysis and amino acid contents of dried green bean vines (as fed).

\begin{tabular}{lc|lc}
\hline Chemical analysis & Component $(\%)$ & Amino acid contents $(\%)$ & Component $(\%)$ \\
\hline DM & 91.74 & Aspartic acid & 1.02 \\
OM & 75.97 & Threonine & 0.34 \\
CP & 12.70 & Serine & 0.34 \\
CF & 21.59 & Glutamic acid & 0.90 \\
EE & 1.60 & Proline & 0.47 \\
NFE & 40.08 & Glycine & 0.35 \\
Ash & 15.77 & Alanine & 0.47 \\
Calcium & 2.05 & Valine & 0.50 \\
Phosphorous & 0.18 & Methionine & 0.12 \\
DE $($ kcal / kg)* & 2243 & Isoleucine & 0.37 \\
Fiber fractions $(\%):$ & Leucine & 0.63 \\
NDF & 43.11 & Tyrosine & 0.32 \\
ADF & 29.12 & Phenylalanine & 0.43 \\
ADL & 12.97 & Histidine & 0.16 \\
Hemicellulose & 13.99 & Lysine & 0.40 \\
Cellulose & 16.15 & Arginine & 0.42 \\
& & Cysteine & 0.15 \\
\hline
\end{tabular}

*Calculated according to Cheeke (1987): $\quad D E(\mathrm{kcal} / \mathrm{g})=4.36-0.0491$ (\%NDF).

$N D F=$ cellulose + hemicelluloses + lignin, $A D F=$ cellulose + lignin and Hemicellulose $=N D F-A D F$ 


\section{Productive performance:}

The effect of feeding dried GBV on live body weight and body weight gain of growing rabbits from 5 to 15 weeks of age are illustrated in Table (3). The differences among treatments for initial live body weight at 5 weeks of age were insignificant and ranged between 654.29 to $659.64 \mathrm{~g} /$ rabbit. While the live body weight over 5-10 weeks of age had the heaviest with the dietary treatments D2 and D3 being insignificant higher than that of control one (D1) and significant higher than that of D4 and D5. Regarding the total weight gain over the whole growing period (5-15 weeks of age), an insignificant improvements were found with dietary treatments D2, D3 and D4, based on control one (D1), with the best total gain was associated with $20 \%$ dried GBV diet (D3). Otherwise the $40 \%$ dried GBV diet (D5) was significant lower than that of control one in respect of total body gain, being achieved the worst result. These results are in agreement with those obtained by Abdel-Magid (2005) who mentioned that rabbits fed on diets contained either $50 \%$ chickpea straw or $50 \%$ pea straw recorded the heaviest live body weight compared to those fed the other leguminous straw and also the control diet. Also in matching with the present results, rabbits fed on diet containing $100 \%$ kidney bean straw recorded the lowest values for live body weight. Otherwise, earlier results conducted by Hussien (2009) reported that rabbits fed on diets contained 25, 50, 75 and 100\% green bean vines instead of clover hay in the control diets of growing rabbits significantly improved the final body weight and daily gain compared to those of control diet. Abdel-Monein (2013) concluded that increasing green beans by-products in the broiler diets was decreased the body weight and weight gain. This may be due to the presence of some antinutritional factors in most vegetable vines or by-products which may reduce growth when raising its level. In this respect, Muzquize et al. (1999) noted that the main toxic components in Phaseolus vulgaris and its by-products are characterized by growth inhibition in experimental animals. Total feed intake was slightly increased with all dietary treatments, except the treatment (D5) that having high level of dried GBV that being significant lower based on control, over all growing periods. Such results might be due to the slightly improvement of CP and CF digestibility in D2, D3 and D4 and may be, also due to that glutamic acid (Table 2) stimulates absorption in treated tissues and increased intestinal nutrients absorption (Abely et al., 2000). The lowest feed intake from

Table (3): Effect of feeding dried green bean vines on productive performance of growing rabbits at different ages.

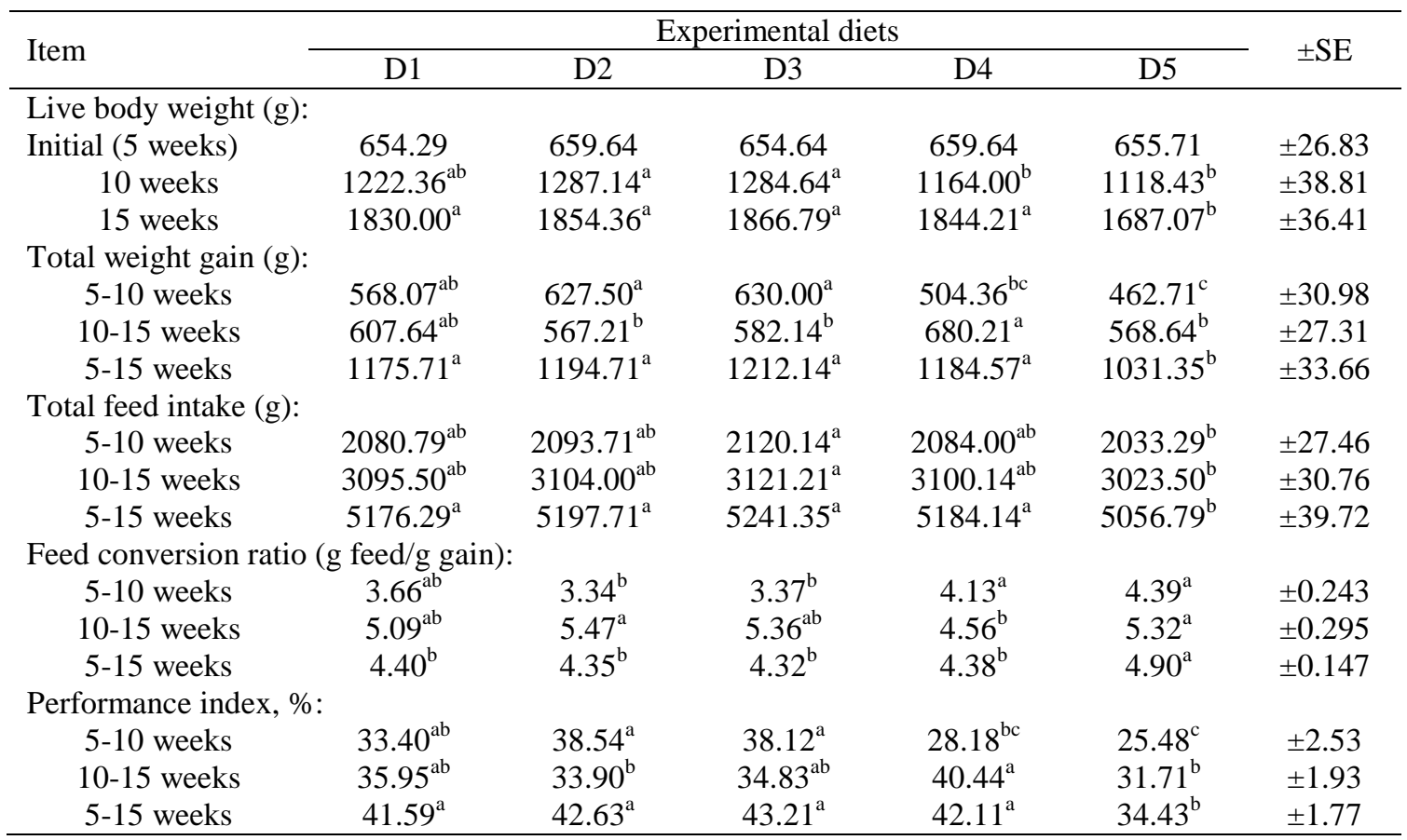

$a, b$ and $c$ : Means in the same row with different superscripts are significantly $(P \leq 0.05)$ different.

SE: standard error.

D1: group that fed the basal diet (control). D2, D3, D4 and D5: groups that fed the basal diet included dried GBV at rate of 10, 20, 30 and $40 \%$, respectively. 
weaning to slaughter that recorded with D5 might due to the significantly decreases of $\mathrm{CP}$ and $\mathrm{CF}$ digestibility as well as due to the oxalate effect which is considerably working as a major factor contributing to the anti-palatability effect of dried GBV which making the diet became less palatable. Saponins are bitter substances which would be expected to adversely influence on feed intake. In this connection, Fenwick and Oakenfull (1983) found that varieties of Phaseolus vulgaris were the richest in saponins content. Hussien (2009) reported that green bean vines contained $2.01 \mathrm{~g} / 100 \mathrm{~g}$ tannins, $10.98 \mathrm{~g} / 100 \mathrm{~g}$ oxalate and $8.20 \%$ saponin of DM. The same author observed that feed intake decreased significantly with increasing the level of pea vines or green bean vines till 26.25 and $35 \%$ in growing rabbit diets, respectively. Villalobos et al. (2010) reported that as dietary intake of cull pinto beans (Phaseolus vulgaris) increased, correspondingly daily gain decreased in lambs diets. These results are in agreement to those obtained by Abd El-Khalik (2002) who used Phaseolus vulgaris straw as fiber source instead of clover hay in NZW rabbit diets at levels of 0, 10, 20 and 30\% from 6 to 14 weeks of age and showed that the rabbits fed $30 \%$ Phaseolus vulgaris diet consumed more daily amount of feed, while control group recorded the lowest. Regarding feed conversion trait, results revealed that mostly there were insignificant effect due to the addition of different levels of dried GBV into the diets of rabbits in compared with control one. It means that dried GBV could be incorporated in the rabbits diets up to $30 \%$ without causing any adverse effect on the productive performance. Rabbits of D2, D3 and $\mathrm{D} 4$ showed better $(\mathrm{P}<0.05)$ feed conversion than the other groups, being the best value occurred with (D3) and the worst one was associated with (D5) over the whole period of the feeding trial. These results are in agreement with those obtained by Hussien (2009) who found that feed conversion was improved by replacing 25 and $50 \%$ green bean vines instead of clover hay compared to the control group. The improvement in growth performance as well as feed conversion in general, could be explained by the improvement in the nutrients digestibilities of the diets contained GBV compared to the control group. Concerning the performance index measurement, its values over the diets contained up to $30 \%$ dried GBV level did not significant differ in comparison with that of control one, being the value of $40 \%$ dried GBV diet (D5) was significant lower than that of control particularly over the whole experimental period. Performance index was unaltered among groups of NZW rabbits fed 0, 10, 20 and 30\% Phaseolus vulgaris containing diets during the whole period from 6 to 14 weeks of age (Abd El-Khalik, 2002).

\section{Digestibility and feeding values:}

Chemical composition of the experimental diets for growing rabbits is presented in Table (4). Comparable values respecting the contents of $\mathrm{CP}, \mathrm{CF}, \mathrm{EE}$ and NFE were observed among the experimental diets. No significant differences were found among all experimental treatments for digestibility of all nutrients and TDN and DCP values as well, despite all values of the mentioned items were the lowest with treatment D5 (Table 5). Hussien (2009) concluded that green bean vines has higher nutritive values which expressed as TDN, DCP and DE and, also these values are nearly similar to those of clover hay which is the main source of fiber that most widely used in rabbit diets. Increasing dried GBV level in rabbit diets up to $40 \%$ decreased nutrients digestibilites that might be due to the oxalate effect which is considerably working as a major factor contributing to the anti-palatability effect of dried GBV as recorded by Oke (1969) who reported that oxalates affect $\mathrm{Ca}$ and $\mathrm{Mg}$ metabolism and react with proteins to form complexes which have an inhibitory effect on peptic digestion. The presence of tannins was found to be decrease the nutritional value of feedstuffs for non-ruminant animals by reducing retention of protein, digestibility of dry matter and metabolic rate of gross energy as well as inhibition of digestive enzyme activity (Li and Zhang, 1998). Arija et al. (2006) showed that increasing the raw kidney bean and extruded kidney bean in broiler chick diets cause a negative effect on performance and $\mathrm{CP}$ digestibilities. Hussien (2009) showed that no significant differences among all groups in digestibility of nutrients and feeding values for control or GBV diets.

Table (4): Chemical composition of the experimental diets of growing rabbits (\% on DM basis).

\begin{tabular}{lcccccc}
\hline Experimental diets & OM & CP & CF & EE & NFE & Ash \\
\hline D1 & 93.27 & 18.84 & 15.59 & 2.70 & 56.14 & 6.73 \\
D2 & 92.29 & 18.43 & 15.13 & 2.67 & 56.06 & 7.71 \\
D3 & 91.30 & 18.70 & 15.01 & 2.59 & 55.00 & 8.70 \\
D4 & 90.31 & 18.93 & 14.90 & 2.51 & 53.97 & 9.69 \\
D5 & 89.30 & 18.99 & 14.86 & 2.42 & 53.03 & 10.70 \\
\hline
\end{tabular}


Khayyal et al.

Table (5): Effect of feeding dried green bean vines on digestion coefficients of nutrients and feeding values of growing rabbits.

\begin{tabular}{lcccccccc}
\hline \multirow{2}{*}{ Experimental diets } & \multicolumn{9}{c}{ Digestibility \% } & \multicolumn{3}{c}{ Feeding values \% } \\
\cline { 2 - 8 } & DM & OM & CP & CF & EE & NFE & DCP & TDN \\
\hline D1 & 67.16 & 69.36 & 72.53 & 33.46 & 83.57 & 77.29 & 13.66 & 66.80 \\
D2 & 67.56 & 69.37 & 72.15 & 33.58 & 83.20 & 76.97 & 13.30 & 65.61 \\
D3 & 68.44 & 69.99 & 73.73 & 34.89 & 83.99 & 78.97 & 13.79 & 66.64 \\
D4 & 66.06 & 69.82 & 72.98 & 33.44 & 84.17 & 77.83 & 13.81 & 65.09 \\
D5 & 63.62 & 67.55 & 69.71 & 27.26 & 83.05 & 77.13 & 13.24 & 62.35 \\
\hline
\end{tabular}

Differences within the same column were not significant.

D1: group that fed the basal diet (control). D2, D3, D4 and D5: groups that fed the basal diet included dried GBV at rate of $10,20,30$ and $40 \%$, respectively.

\section{Carcass traits:}

Effect of dried GBV diets on carcass traits and chemical composition of meat are presented in Tables (6, 7 and 8). Overall, treatments D2 and D3 were achieved the best results in respect of preslaughter weight, empty carcass weight as well as the dressing percentage in comparison with control (D1) and the other tested diets (D4 \& D5). Regarding the weights and percentages of edible giblets and non-edible parts, it could be observed no clear trend among the experimental treatments concerning these traits. Results obtained on the present study are in agreement with the findings of Hussien (2009) who indicated that the $17.5 \%$ GBV recorded higher $(\mathrm{P}<0.05)$ dressing percentage than the $8.75 \%$ GBW level. At the same time, insignificant differences were found between 17.5, 26.25 and 35\% levels in dressing \%. The increase of the inclusion level of green bean in the diets resulted in a significant $(\mathrm{P}<0.05)$ decrease in the total edible parts and dressed weight percentages of the chickens (AbdelMonein, 2013). There were no significant differences among most tested treatments and control one in respect of weights and percentages of coat and head. Likewise weights and percentage of liver, kidneys and heart did not significant affected by treatments. Otherwise intestine weight was lower significantly with D2 than the control and the other tested diets. Zeweil (1992) reported that the inclusion of pea residues to the Flander rabbit diets up to $25 \%$ had no effect on slaughter yield. However, the dressing percentage was significantly $(\mathrm{P}<0.05)$ depressed with the diet contained $50 \%$ of pea residues. While, there were no significant differences in weights of liver, heart and kidneys. Tag El-Din et al. (2002) claimed that carcass traits were not affected by inclusion of Phaseolus vulgaris straw instead of clover hay in rabbit diets at $0,10,20$ or $30 \%$ levels of the diets. Effect of dried GBV levels on chemical composition of experimental rabbit meat are shown in Table (8). There were no significant differences among the dietary treatments in respect of contents of moisture, CP, EE and ash. Pote et al. (1980) noted that fat levels in rabbit meat (as \% of dry weight) being $4.9 \%$ for rabbits fed a low energy diets of fresh forage and $14.1 \%$ for rabbits fed a pelleted commercial diet. Generally, Cheeke (1986) reported that rabbit meat is high in protein and low in fat. Abdel-Magid (2005) reported that rabbits fed different leguminous straw (pea straw, kidney bean straw and chickpea straw) had a

Table (6): Effect of feeding dried green bean vines on carcass traits of growing rabbits.

\begin{tabular}{|c|c|c|c|c|c|c|c|c|c|}
\hline \multirow{2}{*}{$\begin{array}{l}\text { Experimental } \\
\text { diets }\end{array}$} & \multirow{2}{*}{$\begin{array}{c}\text { Pre-slaughter } \\
\text { (fasted) } \\
(\mathrm{g})\end{array}$} & \multicolumn{2}{|c|}{$\begin{array}{l}\text { Empty carcass } \\
\text { (with head) }\end{array}$} & \multicolumn{2}{|c|}{$\begin{array}{c}\text { Dressing } \\
\text { (total edible parts) }\end{array}$} & \multicolumn{2}{|c|}{ Edible giblets } & \multicolumn{2}{|c|}{ Non-edible parts } \\
\hline & & $(g)$ & $\%$ & $(\mathrm{~g})$ & $\%$ & (g) & $\%$ & (g) & $\%$ \\
\hline D1 & $1912.00^{\mathrm{a}}$ & $1070.03^{b}$ & $55.96^{b}$ & $1159.58^{\mathrm{a}}$ & $60.65^{b}$ & $89.55^{\mathrm{ab}}$ & $4.68^{\mathrm{ab}}$ & $752.42^{\mathrm{ab}}$ & $39.35^{\mathrm{b}}$ \\
\hline D2 & $1922.50^{\mathrm{a}}$ & $1140.40^{\mathrm{ab}}$ & $59.32^{\mathrm{a}}$ & $1220.00^{\mathrm{a}}$ & $63.46^{\mathrm{a}}$ & $79.60^{\mathrm{b}}$ & $4.14^{\mathrm{ab}}$ & $702.50^{\mathrm{b}}$ & $36.54^{\mathrm{c}}$ \\
\hline D3 & $1977.50^{\mathrm{a}}$ & $1146.00^{\mathrm{a}}$ & $57.95^{\mathrm{a}}$ & $1225.40^{\mathrm{a}}$ & $61.97^{\mathrm{ab}}$ & $79.40^{\mathrm{b}}$ & $4.02^{\mathrm{b}}$ & $752.10^{\mathrm{ab}}$ & $38.03^{\mathrm{bc}}$ \\
\hline D4 & $1915.00^{\mathrm{a}}$ & $1068.02^{b}$ & $55.77^{\mathrm{b}}$ & $1158.65^{\mathrm{a}}$ & $60.50^{\mathrm{b}}$ & $90.63^{\mathrm{ab}}$ & $4.73^{\mathrm{a}}$ & $756.35^{\mathrm{a}}$ & $39.50^{\mathrm{b}}$ \\
\hline D5 & $1777.50^{\mathrm{b}}$ & $964.78^{c}$ & $54.28^{\mathrm{b}}$ & $1041.23^{\mathrm{b}}$ & $58.58^{c}$ & $76.45^{\mathrm{b}}$ & $4.30^{\mathrm{ab}}$ & $736.27^{\mathrm{ab}}$ & $41.42^{\mathrm{a}}$ \\
\hline$\pm \mathrm{SE}$ & \pm 34.23 & \pm 23.29 & & \pm 24.93 & & \pm 4.36 & & \pm 15.64 & \\
\hline
\end{tabular}


Egyptian J. Nutrition and Feeds (2018)

Table (7): Effect of feeding dried green bean vines on carcass traits of growing rabbits.

\begin{tabular}{|c|c|c|c|c|c|c|c|c|c|c|c|c|}
\hline \multirow{2}{*}{$\begin{array}{l}\text { Experimental } \\
\text { diets }\end{array}$} & \multicolumn{2}{|c|}{ Coat } & \multicolumn{2}{|c|}{ Head } & \multicolumn{2}{|c|}{ Liver } & \multicolumn{2}{|c|}{ Kidneys } & \multicolumn{2}{|c|}{ Heart } & \multicolumn{2}{|c|}{ Intestine } \\
\hline & (g) & $\%$ & (g) & $\%$ & (g) & $\%$ & (g) & $\%$ & (g) & $\%$ & (g) & $\%$ \\
\hline D1 & $211.45^{\mathrm{ab}}$ & $11.06^{\mathrm{ab}}$ & $111.28^{\mathrm{a}}$ & $5.82^{\mathrm{ab}}$ & 70.03 & $3.66^{\mathrm{ab}}$ & 12.33 & 0.645 & 7.20 & 0.377 & $353.75^{\mathrm{a}}$ & $18.50^{b}$ \\
\hline D2 & & $11.42^{\mathrm{ab}}$ & $90^{\mathrm{a}}$ & $6.13^{\mathrm{a}}$ & 1.60 & $3.20^{\mathrm{ab}}$ & & 0 & 6.48 & 37 & $292.50^{\mathrm{b}}$ & $15.21^{\mathrm{c}}$ \\
\hline D3 & 211.1 & $10.68^{b}$ & $114.75^{\mathrm{a}}$ & $5.80^{\mathrm{ab}}$ & 61.33 & $3.10^{\mathrm{b}}$ & 11.60 & .587 & 6. & 8 & $350.00^{\mathrm{a}}$ & $17.70^{\mathrm{b}}$ \\
\hline D4 & $244.60^{\mathrm{a}}$ & $12.77^{\mathrm{a}}$ & $111.27^{\mathrm{a}}$ & $5.81^{\mathrm{ab}}$ & 72.57 & $3.79^{\mathrm{a}}$ & 11.93 & 0.623 & 6.13 & 0.320 & $348.25^{\mathrm{a}}$ & $18.19^{\mathrm{b}}$ \\
\hline D5 & $200.43^{\mathrm{b}}$ & $11.28^{\mathrm{ab}}$ & $98.53^{b}$ & $5.54^{\mathrm{b}}$ & 59.03 & $3.32^{\mathrm{ab}}$ & 11.33 & 0.637 & 6.10 & 0.343 & $381.25^{\mathrm{a}}$ & $21.45^{\mathrm{a}}$ \\
\hline$\pm \mathrm{SE}$ & \pm 12.69 & & \pm 2.32 & & \pm 4.19 & & \pm 0.485 & & \pm 0.367 & & \pm 12.13 & \\
\hline
\end{tabular}

$a, b$ and $c$ : Means in the same column with different superscripts are significantly $(P \leq 0.05)$ different.

SE: standard error.

D1: group that fed the basal diet (control). D2, D3, D4 and D5: groups that fed the basal diet included dried GBV at rate of 10, 20, 30 and $40 \%$, respectively.

Table (8): Effect of feeding dried green bean vines on chemical analysis of meat of growing rabbits (\% on DM basis).

\begin{tabular}{lccccc}
\hline \multirow{2}{*}{ Item } & \multicolumn{5}{c}{ Experimental diets } \\
\cline { 2 - 6 } & D1 & D2 & D3 & D4 & D5 \\
\hline Moisture & 75.86 & 75.58 & 75.81 & 75.51 & 75.89 \\
CP & 88.46 & 89.38 & 89.81 & 89.84 & 88.96 \\
EE & 5.68 & 5.63 & 4.87 & 4.63 & 4.50 \\
Ash & 4.75 & 4.80 & 4.90 & 5.07 & 5.19 \\
\hline
\end{tabular}

Differences within the same row were not significant.

D1: group that fed the basal diet (control). D2, D3, D4 and D5: groups that fed the basal diet included dried GBV at rate of 10, 20, 30 and $40 \%$, respectively.

highly significant $(\mathrm{P}<0.01)$ effect on moisture and $\mathrm{CP}$. While, there were no differences in both EE and ash contents of rabbit meat. Hussien (2009) indicated that no significant differences in CP content of rabbit meat were noticed among the rabbits groups fed control or GBV diets. Much explicity, the insignificant differences among the dietary treatments in the present study, in respect of the chemical composition meat might be excessively due to the isonitrogenous and isocaloric status as the experimental diets (Table 4).

\section{Some blood parameters:}

Data presented in Table (9) showed no significant differences among dietary treatments in respect of concentrations of glucose, cholesterol, total protein, albumin, globulin, AST, ALT, urea and creatinine. The non-significant effects of dietary treatments on most blood metabolites may be due to the adequacy of nutrients especially CP. Excessively plasma total protein and albumin have been reported to be directly responsive to protein intake and quality (Onifade and Abu, 1998). Tag El-Din et al. (2002) reported that the cholesterol concentration and ALT were not affected by replacing Phaseolus vulgaris straw instead of clover hay in rabbit diets at levels of $0,10,20$ or $30 \%$ of the diet. Abdel-Magid (2005) showed that the use of pea straw, kidney bean straw or chickpea straw instead of clover hay did not adversely affect on the biological components of AST, ALT and albumin concentrations, but increased the blood total protein and globulin. Arija et al. (2006) showed that increasing the raw kidney bean and extruded kidney bean in broiler chick diets did not affect blood parameters, except for total protein. The normal range of the total protein values obtained implied therefore that the dietary protein was well utilized. AST and ALT levels reflected that the picture of liver function is within the normal range. In general, the enzymes are intimately related to metabolic processes which in turn, are easily and often influenced by the external environment including feeding practice, climate and all other factors of management (Young at al., 1969). Hussien (2009) reported that the plasma total protein, albumin, globulin, AST, ALT, creatinine, urea and cholesterol concentrations were found to be within the normal range of blood plasma of rabbits fed the vegetable crop wastes. Feeding GBV had positive effect on increasing blood total protein, globulin and urea concentration and lower blood cholesterol 


\section{Khayyal et al.}

concentration compared to the control that free from GBV ingredient. Abdel-Monein (2013) showed that the use of green bean processing by-products in the broiler diets was recorded blood parameters of the chickens to be in normal ranges.

Table (9): Effect of feeding dried green bean vines on some blood parameters of growing rabbits.

\begin{tabular}{lcccccc}
\hline \multirow{2}{*}{ Item } & \multicolumn{5}{c}{ Experimental diets } & \multirow{2}{*}{ \pm SE } \\
\cline { 2 - 6 } & $\mathrm{D} 1$ & $\mathrm{D} 2$ & $\mathrm{D} 3$ & $\mathrm{D} 4$ & $\mathrm{D} 5$ & \\
\hline Glucose $(\mathrm{mg} / \mathrm{dl})$ & 91.00 & 78.33 & 83.33 & 95.33 & 99.67 & \pm 8.45 \\
Cholesterol $(\mathrm{mg} / \mathrm{dl})$ & 92.47 & 91.70 & 90.80 & 88.70 & 87.97 & \pm 2.41 \\
Total protein $(\mathrm{g} / \mathrm{dl})$ & 5.21 & 5.83 & 5.99 & 5.22 & 5.00 & \pm 0.416 \\
Albumin $(\mathrm{g} / \mathrm{dl})$ & 2.32 & 2.48 & 2.71 & 2.48 & 2.32 & \pm 0.300 \\
Globulin $(\mathrm{g} / \mathrm{dl})$ & 2.89 & 3.35 & 3.28 & 2.74 & 2.68 & \pm 0.475 \\
AST $(\mathrm{U} / \mathrm{L})$ & 26.04 & 32.23 & 36.37 & 32.20 & 43.62 & \pm 5.89 \\
ALT (U/L) & 30.45 & 31.40 & 32.71 & 32.76 & 37.11 & \pm 3.88 \\
Urea (mg/dl) & 35.00 & 39.03 & 32.47 & 31.63 & 34.93 & \pm 4.58 \\
Creatinine (mg/dl) & 1.11 & 1.10 & 1.08 & 1.04 & 1.03 & \pm 0.079 \\
\hline Differences within the same row were not significant. & SE: standard error. & & &
\end{tabular}

D1: group that fed the basal diet (control). D2, D3, D4 and D5: groups that fed the basal diet included dried GBV at rate of 10, 20, 30 and $40 \%$, respectively.

\section{Cecum activity:}

Cecum activity data of growing rabbits feeding the experimental diets are presented in Table (10). It could be observed that concentration of TVFA's in the cecum contents was insignificant higher in rabbits fed on the all tested diets than that of control group (D1) and this are in agreement with the findings of Hussien (2009) who showed that TVFA's value was higher with rabbits group fed green bean vines diets and with Rangel et al. (2017) who reported that lambs fed cull pinto beans (Phaseolus vulgaris) led to an increases the volatile fatty acids. Cecum weight or percentage significantly increases with D5 in corresponding with control diet, while no significant differences between the rest of tested diets and control. This is may be due to slower rate of passage of digesta in the gut and in turn related to higher retention time of digesta in the cecum and also may be related to the higher fermentation rate of microflora in the cecum. Concerning the other cecum fermentative items, concentrations of ammonia-N and $\mathrm{pH}$ values were slightly decreased with increasing the levels of dried GBV in the diets. The production of ammonia and amines is quite common during fermentation as a result of protein hydrolysis. Greatly, the interaction of feed ingredients can affect positively or negatively on the whole fermentative processes in the cecum and its end products, because their effect on feed intake or their synergistic as antagonistic interactions with other feeds in the diet (Thomas, 1990). Related to this point, Huhtanen (1991) added that the utilization of dietary energy depends not only on the profile of nutrients made available from a particular feed, but also from nutrients made available from other feeds that incorporated in a diets. It is well known that TVFA's are the main products of microbial fermentation of carbohydrates; consequently, their concentration in the cecum and other fermentative areas can be used as an indirect estimation of microbial activity. In agreement with the present result, Arija et al. (2006) concluded that the inclusion of kidney bean in chicken diets cause a negative effect on performance and $\mathrm{CP}$ digestibilities, and modified digestive organ sizes, intestinal viscosity, cecal $\mathrm{pH}$, and some blood parameters. These results coincided with results obtained by Hussien (2009) who observed that no significant differences in $\mathrm{pH}$ values among the control or GBV diets.

\section{Economic efficiency:}

From the economical point of view the profitability of partial inclusion of dried GBV in the diets of growing rabbits was the best for the high levels (30 and 40\%), but if productive performance, digestion coefficient and dressing \% were taken in the consideration, 10-30\% dried GBV can be successfully used as a suitable ingredient in pelleted complete feed for growing rabbits and being more economically than control diet under Egyptian condition, especially in the summer season (Table 11). 
The present results revealed also, that dried GBV at the rate of $30 \%$ could be perform as the lowest total feed cost/ kg gain.

Table (10): Effect of feeding dried green bean vines on cecum activity of growing rabbits.

\begin{tabular}{lccccc}
\hline \multirow{2}{*}{ Experimental diets } & \multicolumn{5}{c}{ Cecum activity } \\
\cline { 2 - 6 } & \multicolumn{2}{c}{ Cecum } & $\begin{array}{c}\text { TVFA's } \\
(\mathrm{mg} / 100 \mathrm{ml})\end{array}$ & $\begin{array}{c}\text { Ammonia-N } \\
(\mathrm{mg} / 100 \mathrm{ml})\end{array}$ & $\mathrm{pH}$ \\
\hline D1 & $122.25^{\mathrm{b}}$ & $6.39^{\mathrm{b}}$ & 3.95 & 43.49 & 6.20 \\
D2 & $118.43^{\mathrm{b}}$ & $6.16^{\mathrm{b}}$ & 3.95 & 38.73 & 6.15 \\
D3 & $124.63^{\mathrm{b}}$ & $6.30^{\mathrm{b}}$ & 4.05 & 37.71 & 6.14 \\
D4 & $128.83^{\mathrm{b}}$ & $6.73^{\mathrm{b}}$ & 4.34 & 37.24 & 6.08 \\
D5 & $143.35^{\mathrm{a}}$ & $8.07^{\mathrm{a}}$ & 4.14 & 36.77 & 6.06 \\
\pm SE & \pm 3.85 & & \pm 0.327 & \pm 2.22 & \pm 0.102 \\
\hline
\end{tabular}

$a$ and $b$ : Means in the same column with different superscripts are significantly $(P \leq 0.05)$ different.

SE: standard error.

D1: group that fed the basal diet (control). D2, D3, D4 and D5: groups that fed the basal diet included dried GBV at rate of 10, 20, 30 and $40 \%$, respectively.

Table (11): Effect of feeding dried green bean vines on economic efficiency of growing rabbits.

\begin{tabular}{lccccc}
\hline \multirow{2}{*}{ Item } & \multicolumn{4}{c}{ Experimental diets } \\
\cline { 2 - 6 } & $\mathrm{D} 1$ & $\mathrm{D} 2$ & $\mathrm{D} 3$ & $\mathrm{D} 4$ & $\mathrm{D} 5$ \\
\hline Price/ kg diet (L.E) & 4.16 & 3.92 & 3.67 & 3.42 & 3.19 \\
Total feed intake/ rabbit (g) & 5176.3 & 5197.7 & 5241.4 & 5184.1 & 5056.8 \\
Total feed cost/ rabbit (L.E) & 21.51 & 20.38 & 19.21 & 17.71 & 16.11 \\
Total weight gain/ rabbit (g) & 1175.7 & 1194.7 & 1212.1 & 1184.57 & 1031.4 \\
Total Feed cost/ kg gain (L.E) & 18.30 & 17.06 & 15.85 & 14.95 & 15.62 \\
Total revenue/ rabbit (L.E) & 41.15 & 41.81 & 42.42 & 41.46 & 36.10 \\
Net revenue/ rabbit (L.E) & 19.64 & 21.43 & 23.21 & 23.75 & 19.99 \\
Economic efficiency (E.EF) & 91 & 105 & 121 & 134 & 124 \\
Relative E. EF\% & 100 & 115.4 & 133.0 & 147.3 & 136.3 \\
\hline
\end{tabular}

Based on prices of the Egyptian market during the experimental period (2017). The price of one ton of clover hay $(12 \% C P)$, barley, yellow corn, soybean meal $(44 \% C P)$, wheat bran, molasses, methionine, vitamins \& minerals mix., salt, lime stone and Di-calcium phosphate were 2400, 5000, 4000, 7500, 3200, 2000, 70000, 25000, 500, 400 and 10000 LE, respectively. Prices of one ton dry green bean and body weight on selling were 500 and 35 LE, respectively. Initial price of rabbit $25 \mathrm{LE}$.

Net revenue $/$ rabbit $(L E)=($ Total revenue $/$ rabbit $(L E))-($ Total feed cost $/$ rabbit $(L E))$.

Economic efficiency $=($ Net revenue/rabbit $(L E)) /($ Total feed cost/rabbit $($ LE) $x 100$.

Feed cost/ $\mathrm{kg}$ gain= Total feed cost/rabbit (LE) x1000/ Total weight gain/rabbit $(\mathrm{g})$.

$D 1=$ group that fed the basal diet (control). D2, D3, D4 and D5=groups that fed the basal diet included dried GBV at rate of 10, 20, 30 and $40 \%$, respectively.

Mutetikka et al. (1990) found that the use of untraditional feedstuffs such as the agricultural byproducts in the diets may helps in solving the problem of acute feed shortage and decrease the cost of feeding. Abd El-Khalik (2002) showed that feeding Phaseolus vulgaris straw for rabbit at 10, 20 and $30 \%$ levels had less feed cost per kg weight gain and higher economical value than that of the control group. Hussien (2009) recommended that the use of GBV at 35\% in growing rabbit diets as cheap and non conventional ingredient could be nutritionally promising as replacing up to $100 \%$ of clover hay in the diets. Moreover, Abdel-Monein (2013) showed that the use of green beans processing by-products in the broilers diet was found to be beneficial from the economic point of view by reducing the total cost of the diet and thus increasing the profit ability. 


\section{Khayyal et al.}

\section{CONCLUSION}

In conclusion, dried green bean vines could be used in feeding of growing rabbits from $10 \%$ up to $30 \%$ of the their diets with no adverse effect on productive performance, carcass traits, physiological functions and economic efficiency and therefore may help in solving the problem of feed shortage and decrease the cost of feeding.

\section{REFERENCES}

Abdel-Monein, M.A. (2013). Effect of using green beans processing by-products with and without enzyme supplementation on broilers performance and blood parameters. J. Agrobiol., 30(1): 43-54.

Abd El-Khalik, H. (2002). Some nutritional aspects in poultry. M.Sc. Thesis, Fac. Agric., Mansoura Univ., Egypt.

Abdel-Magid, Soha S. (2005). Nutritional studies on leguminous straw in feeding growing rabbits. Ph.D. Thesis, Fac. of Agri., Cairo Univ., Egypt.

Abely, M., P. Dallet, M. Biosset and J.F. Desjeux (2000). Effect of cholera toxin on glutamine metabolism and transport in rabbit ileum. American J. Physiology Gastrointestinal and Liver Physiology, 278(5): 789-796.

Abou-Raya, A.K. (1967). Animal and Poultry Nutrition. Dar-El-Maarif, Cairo, (Arabic Textbook).

Agriculture Economics and Statistics (2014). Ministry of Agriculture and Land Reclamation, Economics Affairs Sector, Bulletin of the Agriculture Statistics, (Summer \& Nile crops 2012/2013), October 2014, Egypt, 2: 197.

Agriculture Ministry Decree (1996). The Standard Properties for Ingredients, Feed Additives and Feed Manufactured for Animal and Poultry. El- Wakaee.

AOAC (1996). Association of Official Analytical Chemists. Official Methods of Analysis, $16^{\text {th }}$ edition, Washington, USA.

Arija, I., C. Centeno, A. Viveros, A. Brenes, F. Marzo, J.C. Illera and G. Silvan (2006). Nutritional evaluation of raw and extruded kidney bean (Phaseolus vulgaris L. var. Pinto) in Chicken diets. Poult. Sci., 85: 635-644.

Armstrong, W.D. and C.W. Carr (1964). Physiological Chemistry: Laboratory Directions. $3^{\text {rd }}$ Ed. pp. 75, Bunges Publishing Co. Minneapolis, Minnesota, USA.

Berthelot, M. (1959). Estimation of serum urea. Report Chem. Applique. 1: 248.

Cheeke, P.R. (1986). Potentials of rabbit production in tropical and subtropical agricultural systems. J. of Animal Sci., 63: 1581-1586.

Cheeke, P.R. (1987). Rabbit Feeding and Nutrition. Academic Press. Orlando, Florida, U. S.A.

Christy, C.C. (2010). Difference between L-Glutamic acid and L-Glutamine. www. live strong. com article, 292730, Oct 31/\#ixzz26zYaN6iX.

Conway, E.J. (1958). Micro-diffusion analysis and volumetric error. $4^{\text {th }}$ Ed. The McMillan Co., New York.

Desuki, A. and H.M. El-Noubi (1990). Feed resources development for animal production. Animal Production Research Institute, German Project (GTZ).

Doumas, B., W. Walson and H. Blgga (1971). Albumin standards and measurement of serum with bromocresol green. Clin. Chem. Acta, 31: 87.

Duncan, D.B. (1955). Multiple range and multiple F-Test. Biometrics, 1:42. 
Eadie, J.M., P.N. Hobson and S.O. Mann (1967). A note on some comparisons between the rumen content of barley fed steers and that of young calves also fed on high concentrate rations. J. Anim. Prod., 9: 247.

Elgohary, Fatma A. and Hayam M.A. Abo EL- Maaty (2014). Phaseolus vulgaris straw as a substitute for clover hay in rabbit diets with prebiotic supplementation and feed restriction interaction: influence on nutrient utilization, caecal activity, carcass yield and blood plasma constituents. Global Veterinaria, 13(6): 1010-1021.

El-Noemani, A.A., H.A. El-Zeiny, A.M. El-Gindy, E.A. El-Sahhar, M.A. El-Shawadfy (2010). Performance of some bean (Phaseolus vulgaris L.) varieties under different irrigation systems and regimes. Australian J. Basic and Appl. Sci., 4(12): 6185-6196

Faulkner, W.R. and J.W. king (1976). Fundamentals of Clinical Chemistry: Determination of creatinine concentration $2^{\text {nd }}$ ed N.W. tietz (ed) pp. 994-998, sauders company Philadelphia, USA.

Fenwick, D.E. and D. Oakenfull (1983). Saponin content of food plants and some prepared foods. J. Sci. Food Agric., 34: 186-191.

Goering, H.K. and P.T. Van Soest (1970). Forage Fiber Analysis (apparatus, reagent, procedures and some applications), ARS, US. Dept. Agri. Handbook, Washington, DC. 20402.

Gupta, R., T.R. Chauhau and D. Lall (1993). Nutritional potential of vegetables waste products for ruminants. Bioresource Technology, pp. 263-265.

Huhtanen, P. (1991). Associative effects of feeds in ruminants. Norwegian J. of Agric. Sci. Supp. No. 5: 37-57.

Hussien, Fawzia A.H. (2009). Nutritional evaluation of some vegetable crop wastes used in rabbits feeding. Ph.D. Thesis, Fac. of Agric., Cairo Univ., Egypt.

Hussien, I., M.M. El-Fouly, K.F. El-Baz and A.S. Ghanem (1999). Nutritional quality and the presence of anti-nutrional factors in leaf protein concentrate (LPC). International Journal of Food Sciences and Nutrition, 50: 333-343.

Kathy, H.R. and M.K. Robert, (2009). Value and quality assurance of by-product feeds. Extension beef cattle resource committee, cattle producer library, University of Wisconsin-Extention.

Li, Y. and Y. Zhang (1998). The effects of sorghum tannin on utilization of nutrients. Chinese Animal Magazine, 34 (4): 24-25.

Linn, J.G., M.F. Hutjens, R. Shaver, D.E. Otterby, W.T. Howard and L.H. Kilmer (2002). Feeding the dairy herd. University of Minnesota Extension, Pub. 346.

Maertens, Y., A. Tegegne, A. Yami and N.N. Umunna (2002). Evaluation of non-conventional agroindustrial by-products as supplementary feeds for ruminants: in vitro and metabolism study with sheep. Small Ruminants Research, 44: 25-35.

Mutetikka, D.B., A.B. Carles and M.M. Wanyoike (1990). The effect of level of supplementation to diets of Rhodes grass (Chloris gayana) hay, maize (Zea mays) leaves and sweet potato (Ipomea batatas) vines on performance of grower rabbits. J. of Applied Rabbit Research, 13: 179-183.

Muzquiz, M., C. Burbano, G. Ayet, M.P. Mercedes and C. Cuadrado (1999). The investigation of antinutritional factors in Phaseolus vulgaris. Environmental and varietal differences. Biotechnol. Agron. Soc. Environ., 3(4): 210-216.

North, M.O. (1981). Commercial Chicken Production Manual. $3^{\text {rd }}$ Ed, Avi., Publishing Company. I.N.C. Westport Connecticut, USA.

Oke, O.L. (1969). Oxalic acid in plants and in nutrition. World Review of Nutrition and Dietetics, 10: 263-303.

Onifade, A.A. and O.A. Abu (1998). Productive response of rabbits to supplemental copper in a diet based on tropical feedstuffs. J. Appl. Anim. Res., 13: 129-135.

Pote, L.M., P.R. Cheeke and N.M. Patton (1980). Utilization of diets high in alfalfa meal by weaning rabbits. J. Appl. Rabbit Res., 3: 5-10. 


\section{Khayyal et al.}

Rangel, F.C., G.V. Villalobos, D.D. Díaz and J.A.O. Gutiérrez (2017). Effect of the dietary level of cull pinto beans (Phaseolus vulgaris) on ruminal fermentation, kinetics, and digestibility of hair lambs. R. Bras. Zootec., 46(5): 405-412.

Reitman, S. and S. Frankel (1957). Method for Determination of Amino Transferase Enzymatic Activities. American J. of Clinical Pathology, 28: 56.

Renard, C. (2001). Crop residues in mixed crop/livestock farming systems. CAB International in association with the association with the International Crops Research Institute for the Semi-Arid Tropics and the International Livestock Research Institute, pp. 25-36.

SAS (2004). SAS/STAT 9.1 User's Guide: Statistics, SAS Institute Inc., Cary, N.C., USA.

Sharasia, P.L., M.R. Garg and B.M. Bhanderi (2017). Pulses and their by-products as animal feed, edited by T. Calles \& H.P.S. Makkar. Rome, FAO.

Stein, E.A. (1986). Textbook of Clinical Chemistry, NW Tietz, ed. W.B. Saunders, Philadelphia, pp. 879-886, 1818-1829.

Tag El-Din, T.H., Kh. El-Sherif, H.A. El-Samra and H.A. Hassan (2002). Effect of using graded levels of Phaseolus vulgaris straw in growing rabbits diet. $3^{\text {rd }}$ Sci. Congr. Rabbit production in Hot Climates, 8-11 Oct., pp. 643-659.

Tandon, O.B., R. Bressani, N.S. Scrimshaw and F. LeBeau (1957). Nutritive value of beans, nutrients in Central American beans. J. Agric. Food Chem., 5(2): 137-142.

Thomas, P.C. (1990) Predicting the nutritive value of compound feeds for ruminants. In: J. Wiseman and D.J.A. Cole (eds), Feedstuff Evaluation, Butterworths, London, pp. 301-318.

Trinder, P. (1969). Determination of glucose in blood using glucose oxidase with an alternative oxygen receptor, Ann. Clin. Biochem., 6: 24-27.

Villalobos, G., F. Castillo, D. Domínguez, H. Castillo and J.A. Ortega (2010). Use of waste pinto bean grain on finishing hair lambs. Proceedings of Western Section of American Society of Animal Science, 61: 293-296.

Wortmann, C.S. (2006). Phaseolus vulgaris L. (common bean). Record from PROTA4U. Brink, M. \& Belay, G. (Editors). PROTA (Plant Resources of Tropical Africa/Ressources végétales de l'Afrique tropicale), Wageningen, the Netherlands.

Young, J.E., R.L. Younger, R.D. Rodeleff, L.M. Hunt and I.K. Melaren (1969). Some observations on certain serum enzymes of sheep. American J. of Vet. Research, 21: 641-645.

Zaza, G.H., M.R.M. Ibrahim, A.M. Ali and Fawzia A. Hassan (2009). Nutritional evaluation of some vegetable crops by-products as unconventional feedstuffs in rabbits feeding. Egypt. J. of Rabbit Sci., 19(2): 71-86.

Zeweil, H.S. (1992). Use of a residue from pea (Pisum sativum) processing in feeding growing rabbits. Egypt. Poultry Sci., 12: 17-30. 
تأثير التغذية على العلائق المحتوية على عروش الفاصوليا الخضر اء المجفة علي أداء أرانب الأبري الناميه

\author{
أماني أمين خيال ، وائل عوض مرسي وأميرة سليمان الدغيدي

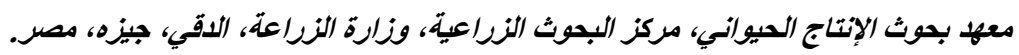

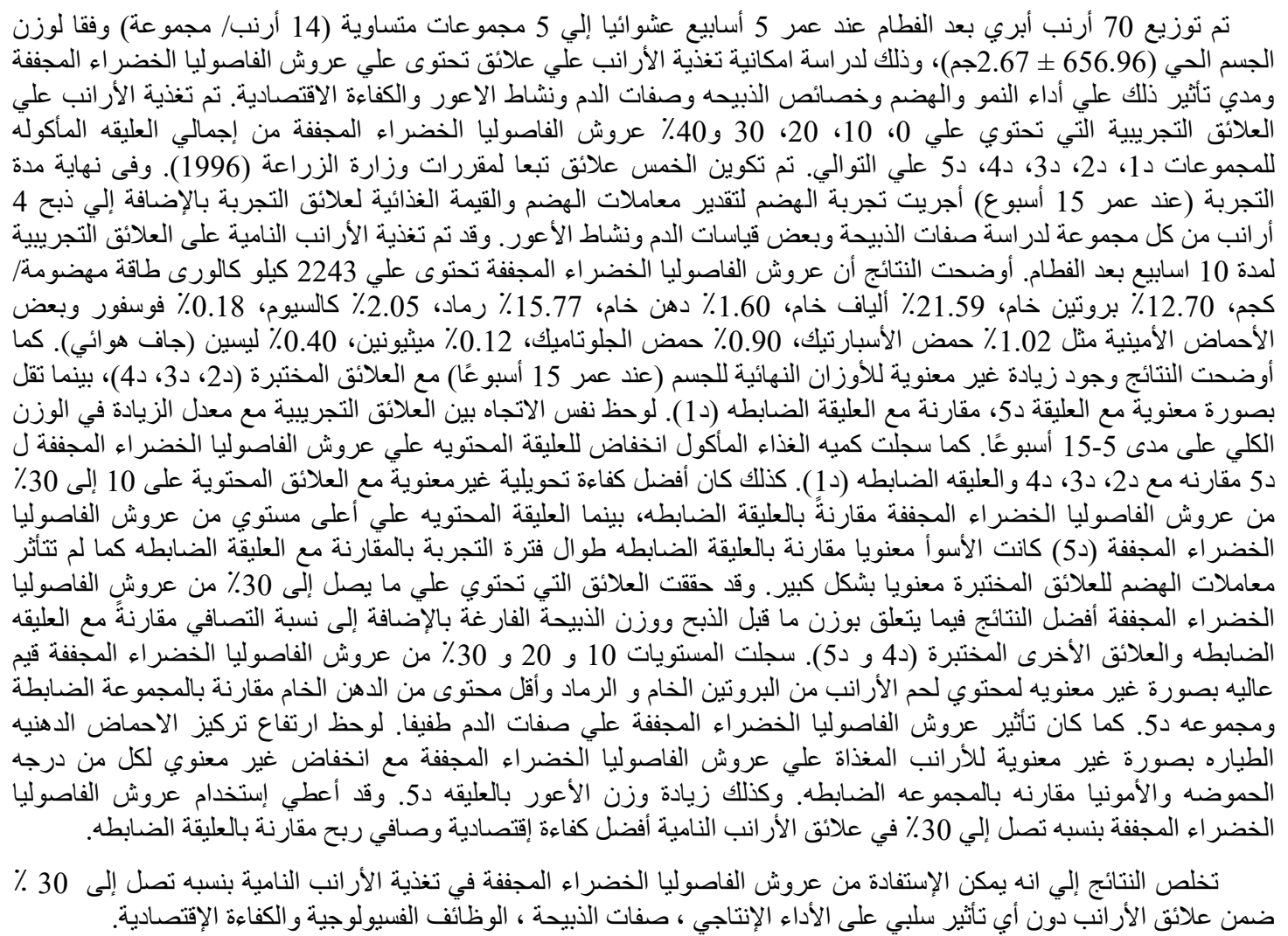

